\title{
RELAÇÃO ENTRE Spironucleus vortens E Citrobacter freundii EM ACARÁ-BANDEIRA Pterophyllum scalare
}

\author{
Spironucleus vortens AND Citrobacter freundii relationship IN FRESHWATER \\ ANGELFISH Pterophyllum scalare
}

\author{
F. A. SEBASTIÃO ${ }^{1 *}$, G. M. R. VALLADÃO ${ }^{1}$, S. U. GALLANI ${ }^{1}$, A. Z. BOARATTI² ${ }^{2}$ F. PILARSKI ${ }^{1}$
}

\section{RESUMO}

Doenças parasitárias e bacterianas são fatores limitantes na produção animal, no entanto, descrições científicas sobre enfermidades que afetam peixes ornamentais são escassas se comparado a outros cultivos. O Acará-Bandeira Pterophyllum scalare, peixe amazônico, é uma das principais espécies da aquariofilia brasileira, sendo exportado e apreciado em todo o mundo. Neste estudo, as causas da mortalidade crônica em Acará-Bandeira P. scalare criados em sistema "in-door" foram pesquisadas. Análise de ectoparasitos da brânquia e tegumento foi realizada com auxílio de lâminas e lamínulas de vidro e o material coletado foi visualizado em microscópio (Nikon E200). Para a pesquisa de endoparasitos, o conteúdo intestinal foi depositado em lâmina de vidro e o tecido também foi raspado com auxílio de uma lamínula. Além disso, descrição patológica (sinais clínicos e alterações macroscópicas) foi realizada durante as necropsias. Para análise microbiológica, rim cranial e baço foram coletados assepticamente, semeados em meio líquido (TSB) e sólido (TSA) e incubados a $30^{\circ} \mathrm{C}$ por $48 \mathrm{~h}$. Colônias purificadas foram submetidas à coloração de gram e coletadas para identificação por PCR de colônia (sequenciamento do gene $16 \mathrm{~S}$ rRNA). Não foram encontrados ectoparasitos nas análises das brânquias e do tegumento. No entanto, na análise intestinal, foi observado elevado grau de infestação por protozoários microscópicos identificados como Spironucleus vortens (dois flagelos e dois núcleos haplóides), os quais apresentavam movimentação clássica (piscando como uma chama de vela). Na análise microbiológica, foi observada colônia rugosa e opaca (formada por bastonetes curtos gram negativos), a qual foi identificada como Citrobacter freundii. Esta é a primeira descrição da associação entre o agente primário $S$. vortens favorecendo a infecção oportunista por $C$. freundii (bactéria comumente encontrada no trato intestinal dos peixes). Este trabalho revela importante diagnóstico e descrição patológica de mortalidade de peixes causada por esta infecção mista na aquicultura.

PALAVRAS-CHAVE: BACTÉRIA. PARASITO. DOENÇA. ORNAMENTAL. PISCICULTURA.

ÁREA TEMÁTICA: Doenças Infecciosas.

\footnotetext{
${ }^{1}$ Laboratório de Patologia de Organismos Aquáticos, Centro de Aquicultura, Faculdade de Ciências Agrárias e Veterinárias de Jaboticabal.

${ }^{2}$ Laboratório de Peixes Ornamentais, Centro de Aquicultura, Faculdade de Ciências Agrárias e Veterinárias de Jaboticabal.

*Autor correspondência: fernanda.sebastiao@gmail.com
} 